\title{
PENGARUH MEDIA PEMBELAJARAN AUDIO VISUAL TERHADAP KEMAMPUAN BERBICARA ANAK KELOMPOK B DI PAUD TERPADU TERATAI UNM MAKASSAR
}

\author{
Miftahul Jannah ${ }^{1)}$, Uswatun Hasanah ${ }^{2)}$ \\ ${ }^{1}$ PAUD Terpadu Teratai Universitas Negeri Makassar \\ email: miftahuljannahusman977@gmail.com \\ ${ }^{2}$ PAUD Terpadu Teratai Universitas Negeri Makassar \\ email: uswatunhasanah@gmail.com
}

\begin{abstract}
Audio visual learning media is a form of stimulation that can be given to improve children's development, especially the development of children. This study aims to find out the description of children's speaking ability using audio visual media, to find out the description of children's speaking ability with the Conversional method, and to determine the effect of the use of audio-visual learning media on the speaking skills of Group B children in Teratai UNM Makassar Kindergarten. This research design uses Quasi Experiment or quasi-experimental. while the sample of the study was group B2 with 11 children for the experimental group and group B1 with 11 children for the control group. Data collection techniques through test, observation and documentation techniques. The data analysis technique used was descriptive statistical analysis and nonparametric statistical analysis. This study shows that there is a significant difference in the development of children's speaking with conventional methods using audio-visual media. As for the calculated $T$ value that is 66 and $T$ table 11 then the results obtained $T$ count (66) $>T$ table (11) H1 is accepted and Ho is rejected means that there is an influence of audio-visual learning media on children's speaking ability. While the calculated $Z$ value obtained is 2.93 and $1.645 \mathrm{Z}$ table, the results obtained $Z$ count (2.93) $>Z$ table (1.645) H1 is accepted and Ho is rejected which means that there is an influence of audio-visual learning media on children's speaking ability. The results of this study indicate that the speaking ability of children receiving treatment in the form of audiovisual media is better than before being given treatment. So it can be concluded that the use of audio-visual learning media influences the speaking ability of Group B children in Teratai UNM Makassar Kindergarten.
\end{abstract}

Keywords: audio-visual learning, speech development, early childhood

Abstrak
Media pembelajaran audiovisual adalah salah satu bentuk stimulasi yang dapat diberikan
untuk meningkatkan perkembangan anak, terutama perkembangan berbica anak. Penelitian
ini bertujuan untuk mengetahui gambaran kemampuan berbicara anak dengan menggunakan
media audiovisual, Untuk mengetahui gambaran kemampuan berbicara anak dengan metode
Konversional, dan Untuk mengetahui pengaruh penggunaan media pembelajaran
audiovisual terhadap kemampuan berbicara anak Kelompok B di Paud Terpadu Teratai
UNM Makassar. Desain penelitian ini menggunakan Quasi Eksperiment atau eksperimen
semu. sedangkan sampel penelitian adalah kelompok B2 berjumlah 11 anak untuk
kelompok eksperimen dan kelompok B1 berjumlah 11 anak untuk kelompok kontrol.
Teknik pengumpulan data melalui teknik Tes, observasi dan dokumentasi. Teknik analisis
data yang digunakan adalah analisis statistk deskriptif dan analisis statistiik nonparametrik.
Penelitian ini menunjukkan bahwa terdapat perbedaan yang signifikan perkembangan
berbicara anak dengan metode konvensional dengan menggunakan media audiovisual.
Adapun nilai $\mathrm{T}$ hitung yang diperoleh yaitu 66 dan $\mathrm{T}$ tabel 11 maka diperoleh hasil $\mathrm{T}$
hitung (66) > $\mathrm{T}$ tabel (11) $\mathrm{H}_{1}$ diterima dan Ho ditolak artinya ada pengaruh media
pembelajaran audiovisual terhadap kemampuan berbicara anak. Sedangkan nilai $\mathrm{Z}$ hitung
yang diperoleh yaitu 2,93 dan $\mathrm{Z}$ tabel 1,645 maka diperoleh hasil $\mathrm{Z}$ hitung (2,93) $>\mathrm{Z}$ tabel
(1,645) $\mathrm{H}_{1}$ diterima dan Ho ditolak yang artinya ada pengaruh media pembelajaran


audiovisual terhadap kemampuan berbicara anak. Hasil penelitian ini menunjukkan bahwa kemampuan berbicara anak yang menerima perlakuan berupa media audiovisual lebih baik dibandingkan sebelum diberikan perlakuan. Maka dapat disimpulkan bahwa penggunaan media pembelajaran audiovisual berpengaruh terhadap kemampuan berbicara anak Kelompok B di Paud Terpadu Teratai UNM Makassar.

Kata Kunci: pembelajaran audiovisual, perkembangan berbicara, anak usia dini.

\section{PENDAHULUAN}

Pada umumnya di Taman KanakKanak, upaya yang dilakukan guru dalam meningkatkan kemampuan berbicara anak dimana guru memberikan pembelajaran hanya sekedar menyampaikan pengetahuan, menyampaikan tentang apa yang harus dilakukan oleh anak, memberikan tugas dan mengefaluasi kegiatan anak berdasarkan tugas yang telah diberikan juga berdasarkan pada pengetahuan pembelajaran yang telah disampaikan oleh guru, dalam artian guru menggunakan metode konvensional yang sangat monoton dan menimbulkan rasa bosan pada anak.

Kegiatan pembelajaran pada dasarnya merupakan proses komunikasi. Dalam proses komunikasi tersebut, guru bertindak sebagai komunikator yang bertugas menyampaikan pesan pembelajaran kepada penerima pesan, yaitu anak. Agar pesan-pesan pembelajaran yang disampaikan guru dapat diterima dengan baik oleh anak maka dalam proses kemunikasi pembelajaran tersebut diperlukan wahana penyalur pesan yang disebut dengan media pembelajaran.

Pemilihan media pembelajaran sangatlah penting dalam proses pembelajaran. Untuk dapat mengembangkan minat dan kemampuan anak dalam berbicara sebaiknya digunakan media yang menarik dan mudah dipahami oleh anak, salah satu media yang dapat digunakan untuk meningkatkan kemampuan berbicara anak adalah dengan menggunakan media pembelajaran audiovisual.

Media audio visual dapat menarik perhatian anak untuk lebih tertarik belajar berbicara. Dengan menggunakan media pembelajaran audio visual juga dapat memudahkan guru dalam menyampaikan materi kepada anak karena dengan media tersebut anak dapat melihat dan mendengarkan huruf dan kata secara langsung.

\section{KAJIAN LITERATUR}

Yusufhadi (Fadlillah, 2012: 206), menyatakan bahwa: Media pembelajaran ialah segala sesuatu yang digunakan untuk menyalurka pesan serta dapat merangsang pikiran, perasaan, perhatian, dan kemauan si pelajar sehingga dapat mendorong terjadinya proses belajar yang disengaja, bertujuan, dan terkendali.

Fadlillah (2012) menyatakan bahwa media pembelajaran untuk anak usia dini dapat digolongkan menjadi tiga, yaitu: "media audio, media visual dan media audio visual".

Menurut Rosyada (2012) Media audio adalah media yang hanya melibatkan indera pendengaran dan hanya mampu memanipulasi kemampuan suara semata. Sedangkan, Media visual adalah media yang melibatkan indera pengelihatan. Jadi, media audio visual adalah media yang melibatkan indera pendengaran dan pengelihatan dalam suatu proses.

Eliyawati (2005: 4.18), mengatakan bahwa: Informasi atau pengetahuan yang diterima melalui indera pendengaran saja (auditori) paling sedikit mengendap dalam seseorang, sedangkan informasi atau pengetahuan yang diterima melalui indera pengelihatan dan pendengaran (audio visual) paling banyak mengendap dalam ingatan seseorang.

Sedangkan Fadlillah (2012: 212) "diantara ketiga macam media, yang baik 
digunakan untuk pembelajaran anak usia dini ialah media audio visual". Sebab media ini telah memadukan antara media pendengaran dan pengelihatan. Dengan menggunakan media ini anak akan lebih mudah memahami materi pembelajaran yang diberikan.

Susanto (2015) berpendapat bahwa bicara adalah bahasa lisan yang merupakan bentuk paling efektif dalam komunikasi, dan bicara merupakan faktor yang paling penting serta paling banyak digunakan dalam berkomunikasi.

Berbicara menurut Hildayani (2011) adalah ekspresi oral dari bahasa, organ manusia yang berperan adalah mulut dan tenggorokan. Tahun pertama dari kehidupan berkomunikasi seorang anak adalah saat paling sibuk dan menarik. Bahkan sebelum ia dilahirkan, anak berhubungan dengan ibu yang sering mengajak anak berbicara walau mereka masih berada dalam kandungan. Sedangkan Zulkifli (2001) kemajuan berbicara harus memiliki latihan-latihan yang tidak ringan, hal ini diperlukan pesiapan untuk belajar bicara. Hal serupa juga dikemukakan oleh Indriati (2011) menyatakan bicara adalah aktivitas kompleks yang melibatkan banyak organ tubuh, tidak hanya mulut, tetapi juga otak, lidah, gigi, pallatum, otot dada, pernapasan, otot leher, pita suara dan diafragma.

Menurut (Hasnida, :137) Media audio visual yang sering digunakan adalah televisi dan film atau vidio. Media ini cukup kuat untuk memberikan informasi, kerana dapat menampilkan suara dan gambar secara bersamaan. Sehingga dengan demikian diharapakan pesan yang diterima anak pun akan lebih kuat terekam dalam ingatannya. Yang selanjutnya akan membantu anak untuk berbicara mengungkapkan pesan-pesan yang diterimanya dengan baik.

Berdasarkan dari pendapat di atas maka dapat disimpulkan bahwa media pembelajaran audio visual dapat digunakan dalam mengajarkan berbicara anak. Media pembelajaran audio visual ini dapat pula digunakan di rumah. Isi materinya pun memiliki banyak pilihan untuk bisa diajarkan untuk anak atau sesuai dengan kemauan anak sendiri. Sehingga sangat diharapkan dengan menggunakan media audio visual di sekolah dapat meningkatkan motivasi anak dalam belajar.

Tujuan penelitian yang ingin dicapai dalam penelitian ini adalah sebagai berikut:

1. Untuk mengetahui gambaran kemampuan berbicara anak dengan penggunaan media audio visual pada anak kelompok B di PAUD Terpadu Teratai UNM Kota Makassar?

2. Untuk mengetahui gambaran kemampuan berbicara anak dengan metode Konversional pada anak Kelompok B di PAUD Terpadu Teratai UNM Kota Makassar?

3. Untuk mengetahui apakah ada pengaruh penggunaan media pembelajaran audio visual terhadap kemampuan berbicara anak Kelompok B di PAUD Terpadu Teratai UNM Kota Makassar.

Berdasarkan latar belakang yang telah dikemukakan tersebut, penulis merumuskan masalah dalam penelitian ini, yaitu:

1. Bagaimanakah gambaran kemampuan berbicara anak dengan penggunaan media audiovisual pada anak kelompok B di PAUD Terpadu Teratai UNM Kota Makassar?

2. Bagaimanakah gambaran kemampuan berbicara anak dengan metode Konversional pada anak Kelompok B di PAUD Terpadu Teratai UNM Kota Makassar?

3. Apakah ada pengaruh penggunaan media pembelajaran audio visual terhadap kemampuan berbicara anak Kelompok B di PAUD Terpadu Teratai UNM Kota Makassar.

\section{METODE PENELITIAN}

Penelitian ini dilakukan dalam waktu \pm 4 minggu. Pendekatan penelitian ini 
adalah pendekatan kuantitatif, yaitu karena jenis data yang diolah dan diproses dari instrumen dalam bentuk angka dengan menggunakan jenis penelitian penelitian Quasi Eksperiment atau eksperimen semu. Metode mempunyai kelompok kontrol, tetapi tidak berfungsi sepenuhnya untuk mengontrol variabel-variabel luar yang mempengaruhi pelaksanaan eksperimen. Sampel diambil dengan cara teknik Purposif Sampling sehingga didapatkan jumlah sampel sebanyak 11 anak untuk kelompok eksperimen dan 11 anak untuk kelompok kontrol. Tekhnik pengumpulan data menggunakan tehnik observasi, tes dan dokumentasi.

Variabel penelitian ini mengaji dua peubah yaitu: media pembelajaran audio visual sebagai peubah bebas atau yang mempengaruhi (dependen) dan kemampuan berbicara sebagai peubah terikat atau yang dipengaruhi (independen). Pengaruh penggunaan media audio visual terhadap perkembangan berbicara anak dapat dilihat perbedaan hasil setelah intervensi yaitu dengan menggunakan uji Wilcoxon.

Data yang diperoleh yaitu dengan menceklis kemampuan berbicara anak pada lembar observasi anak sesuai kategori yang digunakan yang telah dirubah dalam angka-angka sebagai nilai yang dicapai dengan menggunakan skala penilaian. Setelah semua data yang diperoleh sebelum dan sesudah penggunaan media audio visual selanjutnya dianalisis menggunakan statistik deskriptif dan statistik nonparametrik.

\section{HASIL DAN PEMBAHASAN \\ a. Hasil Deskriptif Pretest Kelas Eksperimen}

Tabel 1 : Hasil Deskriptif Pretest Kelas Eksperimen

\begin{tabular}{lllll}
\hline $\begin{array}{l}\mathrm{N} \\
\mathrm{o}\end{array}$ & $\begin{array}{l}\text { Interv } \\
\text { al }\end{array}$ & Kategori & $\begin{array}{l}\text { Freku } \\
\text { ensi }\end{array}$ & $\begin{array}{l}\text { Perse } \\
\text { ntase }\end{array}$ \\
\hline 1. & $15-17$ & $\begin{array}{l}\text { Berkembang } \\
\text { Sangat Baik } \\
\text { (BSB) }\end{array}$ & 1 & $9 \%$ \\
2. & $12-14$ & $\begin{array}{l}\text { Berkembang } \\
\text { Berkmb }\end{array}$ & 2 & $18 \%$
\end{tabular}

Sesuai Harapan

(BSH)

$\begin{array}{llll}\text { 3. } 9-11 & \begin{array}{l}\text { Mulai } \\ \text { Berkembang } \\ \text { (MB) }\end{array} & 6 & 15 \% \\ \text { 4. } 6-8 \quad \begin{array}{l}\text { Belum } \\ \text { Berkembang ( } \\ \text { BB ) }\end{array} & & \\ & & \end{array}$

$\begin{array}{cr}\text { Jumlah } & 11 \\ \text { Sumber: Hasil Survey di Paud Terpadu }\end{array}$ Teratai UNM Makassar

\section{b. Hasil Deskriptif Postest Kelas Eksperimen}

Tabel 2 : Hasil Deskriptif Postest Kelas Eksperimen

\begin{tabular}{|c|c|c|c|c|}
\hline $\begin{array}{l}\mathrm{N} \\
\mathrm{o}\end{array}$ & $\begin{array}{l}\text { Interv } \\
\text { al }\end{array}$ & Kategori & $\begin{array}{l}\text { Freku } \\
\text { ensi }\end{array}$ & $\begin{array}{l}\text { Persent } \\
\text { ase }\end{array}$ \\
\hline 1. & $20-19$ & $\begin{array}{l}\text { Berkembang } \\
\text { Sangat Baik } \\
\text { (BSB) }\end{array}$ & 4 & $36,3 \%$ \\
\hline 2. & $18-16$ & $\begin{array}{l}\text { Berkembang } \\
\text { Sesuai } \\
\text { Harapan } \\
\text { (BSH) }\end{array}$ & 5 & $81,8 \%$ \\
\hline 3. & $15-13$ & $\begin{array}{l}\text { Mulai } \\
\text { Berkembang } \\
\text { (MB) }\end{array}$ & 1 & $90,9 \%$ \\
\hline 4. & $12-10$ & $\begin{array}{l}\text { Belum } \\
\text { Berkembang } \\
\text { (BB) }\end{array}$ & 1 & $9,1 \%$ \\
\hline
\end{tabular}

Jumlah
Sumber: Hasil Survey di Paud Terpadu
Teratai UNM Makassar

\section{c. Hasil deskriptif Pretest Kelas Kontrol}

Tabel 3 : Hasil Deskriptif Pretest Kelas Kontrol

\begin{tabular}{|c|c|c|c|c|}
\hline $\begin{array}{l}\mathrm{N} \\
\mathrm{O}\end{array}$ & $\begin{array}{l}\text { Interv } \\
\text { al }\end{array}$ & Kategori & $\begin{array}{l}\text { Freku } \\
\text { ensi }\end{array}$ & $\begin{array}{l}\text { Perse } \\
\text { ntase }\end{array}$ \\
\hline $\begin{array}{l}1 \\
.\end{array}$ & $16-14$ & $\begin{array}{l}\text { Berkembang } \\
\text { Sangat Baik } \\
\text { (BSB) }\end{array}$ & 1 & 9 \\
\hline $\begin{array}{l}2 \\
.\end{array}$ & $13-11$ & $\begin{array}{l}\text { Berkembang } \\
\text { Sesuai Harapan } \\
(\mathrm{BSH})\end{array}$ & 2 & 18 \\
\hline 3 & $10-8$ & $\begin{array}{l}\text { Mulai } \\
\text { Berkembang } \\
\text { (MB) }\end{array}$ & 6 & 55 \\
\hline $\begin{array}{l}4 \\
.\end{array}$ & $7-5$ & $\begin{array}{l}\text { Belum } \\
\text { Berkembang } \\
(\mathrm{BB})\end{array}$ & 2 & $18 \%$ \\
\hline $\mathrm{Ju}$ & lah & & 11 & $100 \%$ \\
\hline
\end{tabular}


Sumber: Hasil Survey di Paud Terpadu Teratai UNM Makassar

\section{d. Hasil Deskriptif Postest Kelas Kontrol}

Tabel 4 : Hasil Deskriptif Postest Kelas Kontrol

\begin{tabular}{|c|c|c|c|c|}
\hline \\
\hline $\begin{array}{l}\mathrm{N} \\
\mathrm{O}\end{array}$ & $\begin{array}{l}\text { Inter } \\
\text { val }\end{array}$ & Kategori & $\begin{array}{l}\text { Freku } \\
\text { ensi }\end{array}$ & $\begin{array}{l}\text { Persent } \\
\text { ase }\end{array}$ \\
\hline 1. & $19-17$ & $\begin{array}{l}\text { Berkembang } \\
\text { Sangat Baik } \\
\text { (BSB) }\end{array}$ & 1 & $9,1 \%$ \\
\hline 2. & $16-14$ & $\begin{array}{l}\text { Berkembang } \\
\text { Sesuai Harapan } \\
(\mathrm{BSH})\end{array}$ & 3 & $45,4 \%$ \\
\hline 3. & $13-11$ & $\begin{array}{l}\text { Mulai } \\
\text { Berkembang } \\
\text { (MB) }\end{array}$ & 5 & $45,5 \%$ \\
\hline 4. & $10-8$ & $\begin{array}{l}\text { Belum } \\
\text { Berkembang } \\
(\mathrm{BB})\end{array}$ & 2 & $18,1 \%$ \\
\hline $\mathrm{Ju}$ & & & 11 & $100 \%$ \\
\hline
\end{tabular}

\section{Analisis Statistik Non Parametrik Kelompok Eksperimen}

Tabel 6 : Pengaruh Media Pembelajaran Audiovisual Terhadap Kemampuan Berbicara Anak Kelompok Eksperimen

\begin{tabular}{|c|c|c|c|c|c|c|}
\hline \multirow[t]{2}{*}{$\begin{array}{l}\mathrm{Na} \\
\mathrm{ma}\end{array}$} & \multicolumn{2}{|c|}{$\begin{array}{l}\text { Nilai Statistik } \\
\text { Kemampuan } \\
\text { Motorik Halus } \\
\text { Anak }\end{array}$} & \multirow{2}{*}{$\begin{array}{l}\text { Selis } \\
\text { ih } \\
\text { Nilai } \\
(\mathrm{O} 1) \\
- \\
(\mathrm{O} 2)\end{array}$} & \multirow[t]{2}{*}{$\begin{array}{l}\text { Ranki } \\
\text { ng }\end{array}$} & \multicolumn{2}{|c|}{$\begin{array}{l}\text { Tanda } \\
\text { Rangkin } \\
\text { g }\end{array}$} \\
\hline & $\begin{array}{l}\text { Sebel } \\
\text { um } \\
\text { O1 }\end{array}$ & $\begin{array}{l}\text { Sesud } \\
\text { ah } \\
\mathrm{O} 2\end{array}$ & & & + & - \\
\hline $\mathrm{AM}$ & 10 & 17 & 7 & 5 & 5 & \\
\hline $\begin{array}{l}\mathrm{AK} \\
\mathrm{G} \\
\end{array}$ & 11 & 18 & 7 & 5 & 5 & \\
\hline $\mathrm{AJ}$ & 11 & 19 & 8 & 1,5 & 1,5 & \\
\hline $\begin{array}{l}\mathrm{AF} \\
\mathrm{Y}\end{array}$ & 11 & 18 & 7 & 5 & 5 & \\
\hline IF & 14 & 20 & 6 & 8,5 & 8,5 & \\
\hline $\mathrm{FN}$ & 13 & 19 & 6 & 8,5 & 8,5 & \\
\hline $\mathrm{AZ}$ & 17 & 20 & 3 & 11 & 11 & \\
\hline $\mathrm{SB}$ & 11 & 18 & 7 & 5 & 5 & \\
\hline RW & 10 & 17 & 7 & 5 & 5 & \\
\hline $\begin{array}{l}\mathrm{AS} \\
\mathrm{Q}\end{array}$ & 6 & 10 & 4 & 10 & 10 & \\
\hline AR & 7 & 15 & 8 & 1,5 & 1,5 & \\
\hline
\end{tabular}

\begin{tabular}{|c|c|c|}
\hline Jumlah Nilai & 121 & 191 \\
\hline \multicolumn{3}{|c|}{ Nilai $T=66$} \\
\hline Nilai Rata-rata & 13 & 17 \\
\hline
\end{tabular}

Adapun nilai $\mathrm{T}$ hitung yang diperoleh yaitu 66 dan $\mathrm{T}$ tabel 11 maka diperoleh hasil $\mathrm{T}$ hitung (66) $>\mathrm{T}$ tabel (11) $\mathrm{H}_{1}$ diterima dan Ho ditolak artinya ada pengaruh media pembelajaran audio visual terhadap kemampuan berbicara anak. Sedangkan nilai $\mathrm{Z}$ hitung yang diperoleh yaitu 2,93 dan $Z$ tabel 1,645 maka diperoleh hasil $\mathrm{Z}$ hitung $(2,93)>\mathrm{Z}$ tabel $(1,645) \mathrm{H}_{1}$ diterima dan Ho ditolak yang artinya ada pengaruh media pembelajaran audio visual terhadap kemampuan berbicara anak.

Hasil ini menunjukkan bahwa terjadi perubahan nilai pada kemampuan berbicara anak sebelum dan sesudah mendapatkan pembelajaran berdasarkan penggunaan media audio visual. Hal tersebut menunjukkan bahwa kemampuan berbicara anak yang menerima perlakuan berupa media audio visual lebih baik dibandingkan sebelum diberikan perlakuan. Berdasarkan uraian diatas maka dapat disimpulkan bahwa penggunaan media pembelajaran audio visual berpengaruh terhadap kemampuan berbicara anak.

Pengumpulan data dalam penelitian ini diperoleh dengan cara melakukan eksperimen. Desain eksprimen yang digunakan adalah desain yang menggunakan dua kelompok yaitu kelompok eksperimen yang mengikuti pelajaran dengan menggunakan media audiovisual dan kelompok kontrol dengan menggunakan pembelajara konvensional. penelitian Quasi Eksperiment atau eksperimen semu. dimana eksperimen dilaksanakan terhadap dua kelompok untuk dilakukan perbandingan hasil tes awal dan tes akhir pada subjek penelitian.

Langkah pertama dalam pengambilan data adalah dengan melakukan tes awal (Pretest) pada kelompok eksperimen yang mengikuti pelajaran dengan menggunakan 
media audio visual dan kelompok kontrol yang mengikuti pelajaran konvensional . Tes ini dilakukan untuk mengetahui skor siswa sebelum diberi perlakuan (treatment) Setelah dilakukan tes awal, langkah selanjutnya yaitu memberikan perlakuan kepada anak, dalam hal ini bentuk perlakuannya adalah menonton filem dengan menggunakan peralatan LCD, Laptop, dan Speaker. Adapun juduljudul film yang menjadi cerita dalam kegiata ini adalah Diva dan puspus mengenal bentuk huruf (A B C D), kutahu makanan dan minumanku (Roti, nasi \& bubur), Ella \& Ello mengenai isi kamar tidur, Ella \& Ello mengenai isi rumah (televisi, kulkas, radio).

Berdasarkan hasil penelitian terhadap siswa kelas B1 dan B2 Kelompok B di Paud Terpadu Teratai UNM Makassar. didapatkan skor hasil prestest dan posttest dari hasil belajar anak kelas B1 kelompok eksperimen, yang diperoleh dari 5 instrumen penelitian. Dengan kriteria penilaian sebagai berikut: Nilai 4 jika anak mampu melakukan kegiatan dengan sangat baik, maka anak memperoleh nilai 4 (BSB). Nilai 3 Jika anak mampu melakukan kegiatan dengan baik, maka anak memperoleh nilai 3 (BSH), Nilai 2 Jika anak mampu melakukan kegiatan tetapi dengan bantuan guru (MB) Nilai 1 Jika anak belum mampu melakukan kegiatan dengan baik BB.

Berdasarkan hasil analisis uji Wilcoxon menunjukkan terdapat perbedaan yang signifikan antar kemampuan berbicara anak kelompok kontrol dan anak kelompok eksperimen. Perbedaan yang dimaksud adalah rata-rata nilai kemampuan berbicara anak mengalami peningkatan setelah menggunakan media audiovisual dibandingkan nilai kemampuan berbicara anak yang tidak diberi perlakuan (media audiovisual). Hasil Tes Pretest dan Postest kelompok esperimen dan kontrol dapat dilihat dari instrogram dibawah ini:
G.1 Histogram

Nilai Data Pretest dan Posttest Kelompok

Eksperimen

Hasil Data Pretest dan Postest Kelompok eksperimen

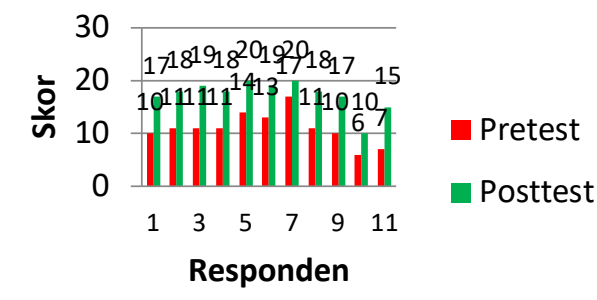

G.2 Histogram

Nilai Data Pretest dan Posttest Kelompok Kontrol

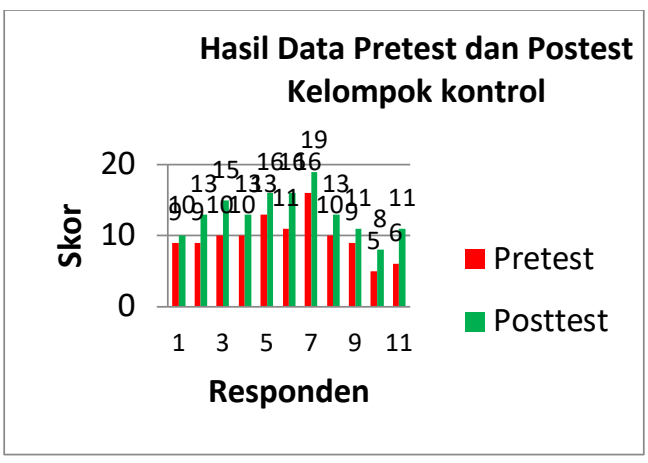

Dalam hal ini, rata-rata hasil skor berbicara anak bagi kelompok anak yang mengikuti pembelajaran dengan media audiovisual lebih tinggi dibandingkan dengan rata-rata hasil skor kemampuan berbicara bagi kelompok anak yang mengikuti pembelajaran dengan metode konvensional.

Hal ini disebabkan karena penggunaan media audio visual mengajak anak untuk mengenal dan mengetahui berbagai hal yang terdapat dalam isi film yang ditampilkan. Serta melatih kemampuan berbicara anak yaitu dengan melakukan kegiatan meniru bahasa serta ucapan yang ada didalam film, juga pada saat anak diajak dalam sesi Tanya jawab mengenai isi film yang ditayangkan. Hal ini berarti, dalam penggunaan media audio visual anak dilatih secara langsung untuk meningkatkan kemampuan berbicaranya.

Pada saat penggunaan media audio visual, anak tidak hanya menjadi 
pembelajar pasif tapi juga aktif, hal ini dapat dilihat pada saat kegiatan menirukan cara berbicara dan pada saat sesi tanya jawab, anak sangat antusias dalam menirukan tokoh dalam film karena terbawa oleh suasana isi film yang kaitannya dekat dengan kehidupan anak.

Penggunaan media audio visual merupakan salah satu stimulasi yang baik untuk mengembangkan kemampuan berbicara anak. Mengacu dengan hal tersebut Arsyad (2011: 4) mengemukakan bahwa "media itu membawa pesan-pesan atau informasi yang bertujuan instruksional atau mengandung maksudmaksud pengajaran maka media itu disebut media pembelajaran. Selain dari pada itu, pendapat yang tidak jauh berbeda dijelaskan oleh Fadlillah (2012: 212) "diantara ketiga macam media, yang baik digunakan untuk pembelajaran anak usia dini ialah media audio visual". Sebab media ini telah memadukan antara media pendengaran dan pengelihatan. Dengan menggunakan media audio visual memberikan manfaat untuk mengembangkan kemampuan berbicara anak karena anak akan lebih mudah memahami materi pembelajaran yang diberikan.

\section{KESIMPULAN}

Berdasarkan analisa pada pembahasan sebelumnya mengenai pengaruh media pembelajaran audio visual terhadap kemampuan berbicara anak kelompok B di PAUD Terpadu Teratai UNM Kota Makassar dapat diambil kesimpulan bahwa kemampuan berbicara anak yang mengikuti pembelajaran konvensional menunjukkan anak belum mampu berbicara dengan baik, hal ini sesuai dengan nilai pemenuhan indikator rata-rata kemampuan berbicara anak berada pada kategori rendah. Sedangkan hasil penelitian kemampuan berbicara anak yang diberi perlakuan media audiovisual menunjukkan anak mampu berbicara dengan baik, hal ini sesuai dengan nilai pemenuhan indikator rata-rata kemampuan berbicara anak berada pada kategori tinggi. Artinya terdapat pengaruh positif penggunaan media audiovisual terhadap kemampuan berbicara anak di PAUD Terpadu Teratai UNM Kota Makassar.

\section{REFERENSI}

Englebringt, Jill. Dan Robert. 2012. Art \& Creative Development for Young Children. 7th Edition. Unites State of America: Wadsworh.

Hildayani Rini. 2011. Psikologi Perkembangan Anak. Jakarta: Universitas Terbuka.

Hurlock. 2005. Psikologi Perkembangan Anak Jilid 1 Edisi Ke-6. Jakarta: Elangga.

Indira. 2009. Yuk Berkreasi dengan Adonan Clay. Jakarta: Gramedia Pusaka Utama.

Kartini, Kartono. 1995. Psikologi Anak. Bandung: Mandar Maju.

Sugiyono. 2010. Metode Penelitian Pendidikan Pendekatan Kuantitatif, Kualitatif, dan R\&D. Bandung: Alfabeta.

Sujiono, Bambang. 2005. Metode Pengembangan Fisik. Jakarta: Universitas Terbuka.

Sumantri. 2005 . Model Pengembangan Keterampilan Motorik Anak Usia Dini. Jakarta: Depdiknas.

Tedjasaputra, S. Mayke. 2007. Bermain, Mainan dan Permainan. Jakarta: PT Grasindo.

Tiro, Muhammad Arif. 2008. Dasar-dasar Statistik. Makassar: UNM. 